\title{
Urban Poverty and its Determinants in Debre Markos City: A Household Level Analysis
}

\section{Debeli Chala Biyena ${ }^{1}$ Endegena Asmamaw Beyene}

Ethiopian Biodiversity Institute, Ethiopia. Email: cchalabiyana@gmail.com

'Arba-Minch University, Ethiopia.

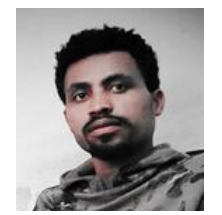

( Corresponding Author)

\begin{abstract}
This study is aimed at examining the extent of urban household poverty using the FGT approach and the national poverty line as a reference. The data were collected from a representative of 316 sample households drawn from each respective kebeles using a combination of simple random sampling and systematic sampling techniques. The findings of the study showed that, the proportion of the poor people is estimated to be $46.8 \%$ indicating that almost half of the people in the study area were unable to meet the monthly per adult equivalent consumption expenditure of 315 ETB. The poverty severity index was also $37.4 \%$ in the study area while it was $2.9 \%$ and $3.2 \%$ at national level and in the region. The estimation result of the logit model also showed that, level of educational achievements, and household income was negatively and significantly correlated with the probability of being poor at $10 \%$ and $1 \%$ significance level respectively. Whereas, the variables that were positively and significantly correlated with the probability of being poor were larger family size, unemployment, not owning a house, and household health status/disease at $1 \%$, $10 \%, 10 \%$, and $1 \%$ level of significance respectively. Based on the result of the study, the following recommendation was made. Efforts should be made to raise the real income of households through wellpaying and steady job creation by the setup of micro and small scale enterprises, with the increased provision of economic and social infrastructure of houses, education, and better water sanitation services for poverty reduction.
\end{abstract}

Keywords: Urban poverty, Poverty headcount, Poverty gap, Poverty severity, Logit model.

Citation | Debeli Chala Biyena; Endegena Asmamaw Beyene (2019). Urban Poverty and its Determinants in Debre Markos City: A Household Level Analysis. Economy, 6(2): 65-75. History:

Received: 9 August 2019

Revised: 12 September 2019

Accepted: 15 October 2019

Published. 2 December 2019

Licensed: This work is licensed under a Creative Commons Attribution 3.0 License (c) ) E

Publisher: Asian Online Journal Publishing Group
Acknowledgement: The authors would like to acknowledge all the local people for actively participating in the study. Government officials and civil servants at different levels, who directly or indirectly involved in this study, are highly appreciated for their assistance especially during the data collection period.

Funding: This study was sponsored by the Arba Minch University.

Competing Interests: The authors declare that they have no conflict of interests.

Transparency: The authors confirm that the manuscript is an honest, Transparency: The authors confirm that the manuscript is an honest,
accurate, and transparent account of the study was reported; that no vital accurate, and transparent account of the study was reported; that no vital
features of the study have been omitted; and that any discrepancies from the study as planned have been explained.

Ethical: This study follows all ethical practices during writing.

\section{Contents}

1. Background of the Study 66

2. Statement of the Problem 66

3. Methodology of the Study 67

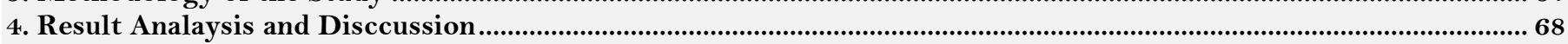

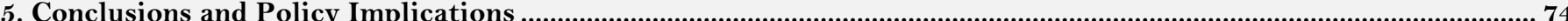

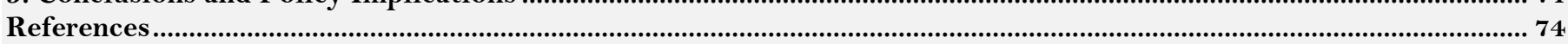




\section{Contribution of this paper to the literature}

This study contributes to existing literature by examining the extent of urban household poverty using the FGT approach and the national poverty line as a reference.

\section{Background of the Study}

Poverty is prevalent in large parts of the world and is one of the largest challenges of mankind in the $21^{\text {st }}$ century. Despite changes in development paradigms in the last half of the $2 \mathrm{O}^{\text {th }}$ century, the promise to bring wellbeing to all human beings remained unfulfilled. One of the major development problems facing the world today is growing phenomenon of poverty. It is estimated that over 1.3 billion people live on less than US $\$ 1.25$ per day, and 1 billion people cannot meet basic requirements. Furthermore, 415 million people (one in every two people) in subSaharan Africa survive on less than US $\$ 1.25$ per day and 184 million people (16 percent of African population) suffer from malnutrition (Sharma et al., 2016).

Ethiopia is among the lowest income countries in the world with an average per capita income of merely US\$ 550 , a very low Human Development Index (HDI) of 0.435 positioning the country at $173^{\text {rd }}$ out of 187 countries, a poverty incidence (Head count Ratio) of 26 percent at US $\$ 1.25$ a day in Purchasing Power Parity (PPP), and urban unemployment rate of 16.5 percent (Ministry of Finance and Economic Development (MoFED), 2013; United Nations Development Programme, 2014).

In 2015, Ethiopia was facing drought due to the effects of El Nino, and about 10.2 million persons were in need of emergency aid into 2016. According to the United Nations Development Program of 2015, about 23 million Ethiopians live in conditions substantially below the basic poverty line and food insecurity remains a major challenge. In the same report 44.2 percent of children under five are malnourished and stunted.

According to the report by Oxford University Poverty and Human Development Index (OPJDI) in 2011, 87 percent of the Ethiopian population was poor as measured by Multidimensional Poverty Indicators (MPI), which means they were deprived in at least one-third of the weighted MPI indicators. This put Ethiopia as the second poorest country in the world when using the MPI approach (OPHDI, 2013).

The multidimensional character of poverty in Ethiopia is reflected in many respects such as, destitution of assets, vulnerability, and human development. Poverty in Ethiopia is also associated with certain household characteristics. For instance, as compared to richer households, poor households in urban centers tend to have a larger proportion of dependents, older household heads, more unemployed family members and more femaleheaded households (Aredo, 2005). Moreover, vulnerability to shocks is more serious in urban areas than in rural areas. This is partly due to the fact that urban households lack assets such as land and livestock, which are available in rural areas. The world is rapidly experiencing urbanization. As urbanization is increasing so also the incidence of urban poverty is increasing in depth and intensity in cities of most of developing countries of the world including Ethiopia. The dimension of urban poverty that manifests in various ways may also include unemployment, poor housing condition characterized in overcrowding, lack of basic services and environmental degradation. In Ethiopia, many urban people do not meet their basic needs (Sumner and Meera, 2015). In 2010, 11 percent of Ethiopia's poor lived in cities, but this percent rose to 14 percent in 2010/11. An estimate by MoFED (2013) pointed out that 27.8 percent of Ethiopian population was absolutely poor (unable to meet basic needs) of which 25.7 percent was urban. The number of poor people stayed almost constant between 2004/05 and 2010/11 at 3.2 million (MoFED, 2013). Even though, the government of Ethiopia has tried to address some problems related to poverty, the focus given to urban areas are not gone with the extent of the problem. High population growth due to rural to urban migration and other internal factors have making life hard in urban Ethiopia. This really can lead to high crime, strikes and other socio-economic and political problems. Therefore, the issues that were addressed in this study can help the federal and local governments to design strategies for sound poverty reduction and to tackle the real problem of urban areas in general and the study area in particular.

\section{Statement of the Problem}

For decades, both rural and urban poverty in Ethiopia has remained pervasive and ever deepening. Despite the decline in the level of poverty currently in Ethiopia, there are about 22.6 million poor people in 2013/14 who are living under the poverty line (which is very close to PPP US\$1.25 a day on food and non-food items) and who are unable to satisfy their basic needs (Sumner and Meera, 2015). Besides, the severity of poverty is also increased between 2005 and 2011. Therefore, reducing poverty among the poorest of the poor, insuring food security and reducing the number of poor people in the country remain priority agenda and area of intervention in the postMillennium Development Goals period (Sumner and Meera, 2015).

In the developing world, little is known about urban poverty from quantitative evidence mainly due to lack of data tracking from the same households overtime (Kedir and McKay, 2003). Similarly, in Africa the analysis of urban poverty dynamics hampered by similar problems and there is diminutive substantiation on such an important dimension of poverty.Earlier studies of poverty in Ethiopia mainly focused on rural areas rather than urban areas (Bigsten et al., 2003; Dercon and Pramila, 2003). There are few studies that explored the poverty situation of urban households in Ethiopia in both a static and dynamic context (Dercon and Taddesse, 1997; Disney et al., 2003). However, they concentrated on assessing the poverty condition of primate and large cities of Ethiopia. In line with the above points, the urban sector in Ethiopia has been neglected and unnoticed by researchers and policy analysts, and also ignored in debates on poverty issues. This has resulted in a' rural bias.'

Even though the effect of urban poverty in Ethiopia is getting severe, the factors that account for the results are not studied very well. Most of the studies have been conducted in rural areas of Ethiopia and attempts on urban sectors are still scanty. Even the studied ones were confined to the primate city Addis Ababa and secondary cities like, Bahir Dar, Nazareth, Awassa, and Mekelle. Poverty status in the Amhara Region remains multifaceted and complex. The 2010/11 HICS survey result showed that in terms of food poverty index, the highest incidence was observed in Amhara region (42.5\%) and the total poverty index was $30.5 \%$ in the region. East Gojjam Zone is one of the sixteen (16) zones of the region and like other Ethiopian urban areas poverty is a major challenge. According to the 2010/11 Ethiopian government poverty assessment report poverty trend in the zone was persistence. 
There were a number of issues that are considered as a limitation of the previous study and make the current study different from the previous one. Among the issues that were considered as a research gap were; one, there is only one research attempt regarding poverty in the study area before 12 years ago by Esubalew (2006). Therefore, we try to estimate and compare the poverty situation of the study area before 12 years ago and the current ones based on different indicators like demographic characteristics, socio-economic indicators, and other households' characteristics, it is quite different. Second, the researcher applied the FEI approach (which shows food poverty only) to address the situation of poverty and to identify poor and non - poor households in the study area. However, the study was conducted in one of the old medium - sized cities, Debre Markos and since cities have a monetized economy. Therefore, as a big limitation in the previous study the researcher does not provide allowance for non - food items in measuring the situation of poverty which is the most important part. Therefore, so as to fill the gap in this study the National poverty Line set by the government was applied, which is based on the Cost of Basic Needs (CBN) approach that provide allowance for non- food items in measuring urban poverty. The last is the application of sampling techniques. For instance, the researcher purposely took 6 kebelles from 12 kebelles, and in that process he had selected 3 kebelles having high socio-economic status based on different indicators and 3 other kebelles having low-socio- economic status and such action may result in sampling bias which might have a negative impact on the finding of the study.

\section{Methodology of the Study}

Debre Markos, the capital city of East Gojjam Administrative Zone is located in the north west of the capital city of Ethiopia, Addis Ababa at a distance of $300 \mathrm{kms}$ and $265 \mathrm{kms}$ to the capital city of Amhara National Regional State, Bahir Dar. Specifically, it is located in the Amhara Regional State, East Gojjam Zone. Until 1995, Debre Markos was the capital city of the province of Gojjam and currently the town served as the capital city of East Gojjam Zone. The city is named as Debre Markos after its principal church, which was constructed in 1869 E.C and is devoted to Saint Mark. Debre Markos is one of the oldest and medium sized cities of Ethiopia and currently, the city has seven (7) kebele administrations (Debre, 2016). It has latitude and longitude of $10^{\circ} 20^{\prime} \mathrm{N}, 37^{\circ} 43^{\prime} \mathrm{E}$ and altitude of 2,446 meters above sea level and it has moderate temperature (Debre, 2016). The area of Debre Markos city is 6,160 ha and has oval shape; its average annual temperature is $18.5^{\circ} \mathrm{C}$; Mean annual rain fall is $1,380 \mathrm{~mm}$ and the existing wind direction is from North to South. The city is administration and commercial center. There are 61 manufacturing industries, 37 wholesale trades, 2101 retail trades, 168 service trades and 6 fuel stations and 6 garages in the town. There are four government and three private banks and one micro- finance giving services in the town. The major investment opportunities in the town are: agro-industry processing, constriction industry, hotel and tourism \& social services. According to CSA, 2007, economic activity rate was 44.2 for sexes, 48.3 and 40.4 for males and females respectively. The rate of unemployment in the same period was $11.8 \%$ for both sexes. The male and female unemployment rate was 9.1 and 14.1 respectively. Debre Markos town has economic linkages with the surrounding areas and Addis Ababa. The town gets grain products, livestock supply, natural resources (fuel wood and charcoal), and labor from surrounding areas manufactured and commercial products from Addis Ababa.

According to CSA (Central Statistical Agency) (2007), the population of the city was 62,497. Out of this $29,921(47.87 \%)$ were males and 32,576(52.1\%) were females; $16,325(26.14 \%)$ were within the age group of $0-15$ years, $42,185(67.49 \%)$ were $16-60$ years, and $3,987(6.37 \%)$ were 61 years and above. The population growth rate at low variant was $2.4 \%$ while household family size in the city is calculated to be 3.2. According to CSA (2013), the population projection of the city had been estimated 38,291 male and 41,689 female inhabitants which is a total of 79,980 populations. Area of the city is expected to be $1214.9 \mathrm{Sq} . \mathrm{km}$ and $65.85 \mathrm{~km} / \mathrm{sq}$. density.

The primary and secondary data sources were used to carry out the study. The sources of the primary data are cross-sectional data collected from the sample that intends to represent the population. On the other hand, secondary data were collected from previous working literatures, the findings stated in published and unpublished documents and literatures related to the research problem. In this study, household survey was the main tool used to gather the necessary data from the sample households. To undertake the survey, structured questionnaire was prepared as instrument and an interview was held to gather information at a household level. The prepared questionnaire was prepared in English and then translated into Amharic. The Amharic version questionnaire was also pre-tested on 20 randomly selected households in similar communities. This was done purposely for clarity, acceptability, flow and reduction of repetition. Finally, the survey was conducted by four selected interviewers and the researcher supervised these four interviewers. A multi-stage sampling technique was employed to get the required primary data. At the first stage, based on the current kebele administration structure, Debre Markos city has 7 (seven) kebeles, therefore, in this study 4 kebeles were selected randomly. Secondly, the 316 households were drawn using systematic random sampling proportionate to household head techniques. The household head list in each representative kebele was used as sampling frame to select sample households. Finally, systematic sampling method was employed to select the first households from each of the kebeles. To make it precise, every $38^{\text {th }}$ of the household were selected from the registration of each kebele based on their house number.

Table-1. Number of sample households taken from sampled kebeles.

\begin{tabular}{c|c|c|c}
\hline No & Name of kebeles & Total No. of households in each kebele & Sample households in each kebele \\
\hline 1 & Kebele O1 & 1222 & 32 \\
\hline 2 & Kebele O2 & 4529 & 118 \\
\hline 3 & Kebele 03 & 3916 & 102 \\
\hline 4 & Kebele 04 & 2463 & 64 \\
\hline \multicolumn{2}{r}{ Grand Total } & 12,130 & 316 \\
\hline
\end{tabular}

In this study, logistic regression model was employed. The dependent variable takes a value of 1 if the household is being poor with the probability of $\mathrm{P}_{\mathrm{i}}$, otherwise takes a value of $\mathrm{O}$, if the household is non poor with the probability of $1-\mathrm{P}_{\mathrm{i}}$. Therefore, Specification of the logit regression model can be shown as follows:

$$
\text { Logit }\left\lfloor\frac{\mathrm{Pi}}{1-\mathrm{Pi}}\right\rfloor=\text { logit of being poor or non }- \text { poor }
$$


Logit $\left(\mathrm{P}_{\mathrm{i}}\right)$ scale ranges from negative infinity to positive infinity and is symmetrical around the logit of 0.5 (which is zero). The formula below shows the relationship between the usual regression equation $(\beta 0+\beta 1 \times 1+$ $\ldots+\beta k x k)$, which is a straight line formula in the logistic regression equation. The form of the logistic regression equation is:

$$
\operatorname{logit}\lfloor\mathrm{Pi}\rfloor=\log \left\lfloor\frac{\mathrm{Pi}}{1-\mathrm{Pi}}\right\rfloor=\beta 0+\beta 1 \times 1+\beta 2 \times 2+\beta 3 \times 3+\cdots+\beta \mathrm{kxk}+\mathrm{Ut}
$$

Where, $\mathrm{P}_{\mathrm{i}}=1$ is the Probability that the household is being poor, $\mathrm{O}$ otherwise.

$1-\mathrm{P}_{\mathrm{i}}=$ the probability that the household is not poor.

$\mathrm{X}_{\mathrm{i}}=$ explanatory variables.

The probability of one becoming poor or non-poor based on the explanatory variables was calculated using the formula given below, which is simply another rearrangement of the formula given above.

$$
P i=\frac{e^{\beta 0+\beta_{1} x_{1}+\beta_{2} x_{2}+\beta_{3} x_{3}+\cdots+\beta_{k} x_{k}}}{1+e^{\beta 0+\beta_{1} x_{1}+\beta_{2} x_{2}+\beta_{3} X_{3}+\cdots+\beta_{k} x_{k}}}
$$

In this study, the explanatory variables $\left(\mathrm{X}_{\mathrm{i}}\right)$ were selected based on available related literatures on the subject at issue. The variables include: age of the household head, sex, marital status, family size, education, main occupation, unemployment, income, home ownership, dependency ratio, health status, number of working hours, seasonality of work, and access to basic services. Therefore, the model for household poverty status can be represented by:

POVERTY =

$f(A G E, S E X, M A R T S, F A M S I Z, E D U C, U N E M P, D E P R, O C U P, I N C O M E, H O M O W N, H H H S, N W K R S, S E S O W K, A B S, \varepsilon)$

Where, $\varepsilon=$ is the random variable $\operatorname{Logit} P_{i}=\beta_{o}+\beta_{1}$ age $+\beta_{2}$ se $x+\beta 3$ marst $+\beta_{f}$ famsiz $+\beta_{s} e d u c+\beta_{6}$ unemp $+\beta_{7}$ depenr $+\beta_{s o c c u p}$

$+\beta_{\text {sincome }}+\beta_{10}$ homown $+\beta_{u t}$ hhhhs $+B_{12} n w k h r s+\beta_{1 s}$ sesowk $+\beta_{14} a b s+\varepsilon$

Table-2. Description of the explanatory variables used in the logistic regression model.

\begin{tabular}{l|l|l|c}
\hline \multicolumn{4}{c}{ Table-2. Description of the explanatory variables used in the logistic regression model. } \\
\hline Variables & Description & Measurement & Expected sign \\
\hline Age & Household head age & Number & $+/-$ \\
\hline Gender & Household head sex & Male=1,0 otherwise & + \\
\hline Marital status & Household head maritalst & Married=1, o otherwise & + \\
\hline Family size & Number of people in household & Number & + \\
\hline Occupation & Household head main occpn & $\begin{array}{l}\text { Gov't employee }=1, \\
\text { otherwise=0 }\end{array}$ & $+/-$ \\
\hline Education & & Illiterate=1,otherwise=0 & - \\
\hline Income & Educational status & Birr & - \\
\hline Unemployment & Level of income & Number & + \\
\hline Dependency & Unemployed members & Number & + \\
\hline Household health & Family dependents & Sick=1,otherwise=0 & $+/-$ \\
\hline $\begin{array}{l}\text { Number of working } \\
\text { hours }\end{array}$ & Wealth status & Number & - \\
\hline Seasonality of work & Season impact & Yes=1, No=0 & $+/-$ \\
\hline Home ownership & Housing status & $\begin{array}{l}\text { Own house }=1, \\
\text { otherwise }=0\end{array}$ & $+/-$ \\
\hline Access to basic services & Credit access & yes=1, No=0 & - \\
\hline
\end{tabular}

\section{Result Analysis and Discussion}

In this section, the socioeconomic and demographic characteristics of the data obtained in household survey were analyzed using descriptive and econometric methods of data analysis. The whole description takes National poverty line as a reference to identify the poor from the non-poor households.

\subsection{Poverty Indices}

To measure the extent of poverty and poverty situation of households, Headcount index $\left(\mathrm{P}_{0}\right)$, Poverty gap index $\left(\mathrm{P}_{1}\right)$, and Poverty severity index $\left(\mathrm{P}_{2}\right)$ are the most important and widely used indices. In this study, based on the poverty line (315 ETB per adult equivalent per month) and the data collected from sampled households, the three (3) poverty indices of the study area were computed as follows:

Headcount Index $\left(\mathrm{P}_{\mathrm{o}}\right)$ :

$$
P_{\alpha}=\frac{1}{N} \sum_{i=1}^{q}\left(\frac{\left.Z-Y_{i}\right)}{Z}\right)^{\alpha}
$$

$$
\mathrm{P}_{\mathrm{O}}=\frac{q}{N}=\frac{148}{316}=0.4683
$$

$$
\begin{aligned}
& \text { Poverty Gap Index }\left(\mathrm{P}_{1}\right)=\frac{1}{N} \sum_{i=1}^{q}\left(\frac{\mathrm{Z}-\mathrm{Yi}}{\mathrm{Z}}\right)^{1} \\
& =\frac{1}{316} \sum_{i=1}^{148}\left(\frac{315-34,544.085}{315}\right) \\
& =\frac{1}{316} \sum_{i=1}^{148}\left(\frac{-34,229.085}{315}\right) \\
& =\frac{1}{316}(-108.66376) \\
& =0.3438
\end{aligned}
$$




$$
\begin{aligned}
& \text { Poverty Severity Index }\left(\mathrm{P}_{2}\right)=\frac{1}{316} \sum_{i=1}^{148}\left(\frac{315-34,544.085}{315}\right)^{2} \\
& =\frac{1}{316}(-108.66376)^{2} \\
& =37.3639
\end{aligned}
$$

Table-3. Poverty indices in the study area.

\begin{tabular}{c|c|c|c}
\hline Poverty Variables & $\begin{array}{c}\text { National } \\
\text { Urban(2010/1 1) }\end{array}$ & $\begin{array}{c}\text { Regional } \\
\text { Urban(2010/11) }\end{array}$ & $\begin{array}{c}\text { Study Area } \\
\text { Debre Markos (2017) }\end{array}$ \\
\hline Headcount Index $\left(\mathrm{P}_{0}\right)$ & $0.279(27.9 \%)$ & $0.292(29.2 \%)$ & $0.468(46.8 \%)$ \\
\hline Poverty Gap Index $\left(\mathrm{P}_{1}\right)$ & $0.073(7.3 \%)$ & $0.080(8.0 \%)$ & $0.344(34.4 \%)$ \\
\hline Poverty Severity Index $\left(\mathrm{P}_{2}\right)$ & $0.029(2.9 \%)$ & $0.032(3.2 \%)$ & $0.374(37.4 \%)$ \\
\hline
\end{tabular}

As can be seen in Table 3 using real per adult consumption expenditure the levels of total urban poverty indices at National level, Regional level and in the study area are provided. As apparent from the table above, the proportion of poor people (poverty headcount index) in the study area is estimated to be 46.8 percent. However, the proportion of poor people at Regional level stood at 29.2 percent and at National level stood at 27.9 percent. Similarly, the Poverty Gap Index in the study area was estimated to be 34.4 percent while it was 8.0 percent in the region and 7.3 percent at national level. The Poverty Severity Index in the study area was estimated to be 37.4 percent while it was 3.2 percent at regional level and 2.9 percent at national level.

\subsection{Descriptive Data Analysis Based on Sample Households Characteristics \\ 4.2.1. Household Family Size and Poverty}

The average family size of the sampled households in the study area was 4.5 which were below the national average of 5 persons (CSA, 2010). The incidence of poverty is invariably noted to be higher among those with larger family sizes. Large households tend to associate with poverty (Lanjouw and Martin, 1995). There is also a widely held view that larger families tend to be poor in developing countries like Ethiopia. As evidenced in Table 4, the highest incidence of poverty which is $27.53 \%$ is observed in those households having $3-5$ family members followed by households having 6-8 family members with poverty incidence of $16.77 \%$ and the lowest incidence of

\begin{tabular}{|c|c|c|c|c|c|c|}
\hline \multirow[t]{3}{*}{ Household family size } & \multicolumn{5}{|c|}{ Household Poverty Status } & \multirow{3}{*}{$\begin{array}{c}\text { Headcount } \\
P_{0}\end{array}$} \\
\hline & \multicolumn{2}{|c|}{ Poor households $(N=148$} & \multicolumn{2}{|c|}{ Non poor households $(\mathrm{N}=168)$} & \multirow[b]{2}{*}{ Total } & \\
\hline & Frequency & percent & Frequency & Percent & & \\
\hline $1-2$ & 2 & 1.35 & 35 & 20.83 & 37 & 0.006 \\
\hline $3-5$ & 87 & 58.78 & 115 & 68.45 & 202 & 0.275 \\
\hline $6-8$ & 53 & 53.81 & 18 & 10.71 & 71 & 0.167 \\
\hline$\geq 9$ & 6 & 4.05 & 1 & 0.59 & 7 & 0.019 \\
\hline Grand Total & 148 & 100 & 168 & 100 & 31 & 0.468 \\
\hline
\end{tabular}
poverty $0.6 \%$ is observed in those households having $1-2$ family members.

Table-4. Poverty incidence by households family size.

\subsubsection{Level of Educational Achievements and Poverty}

As human capital theory predicts, the best investment of all is the one made in people and therefore, greater educational attainment may imply a larger set of employment opportunities thereby increased earning potential and improve occupational and geographical mobility of labor. Education can serve as an important tool for escaping from poverty. As Table 5 reveals, the incidence of poverty is higher for those households having low level of educational achievements like illiterate households and those households able to read and write with $13.9 \%$ and $11.4 \%$ of poverty incidence followed by households having primary and secondary education with poverty incidence of $7.3 \%$ and 5.4. In the case of those households having Diploma/TVET and Degree the incidence of poverty is

\begin{tabular}{|c|c|c|c|c|c|c|}
\hline \multirow{3}{*}{ Level of Education } & \multicolumn{4}{|c|}{ Household Poverty Status } & \multirow{3}{*}{ Total } & \multirow{3}{*}{$\begin{array}{c}\text { Headcount } / \\
P_{o}\end{array}$} \\
\hline & \multicolumn{2}{|c|}{$\begin{array}{c}\text { Poor } \\
\text { households }(\mathrm{N}=148)\end{array}$} & \multicolumn{2}{|c|}{$\begin{array}{c}\text { Non-poor } \\
\text { households }(N=168) \\
\end{array}$} & & \\
\hline & Frequency & Percent & Frequency & Percent & & \\
\hline Illiterate & 44 & 29.73 & 13 & 7.74 & 57 & 0.139 \\
\hline Read \& write & 36 & 24.32 & 4 & 2.38 & 40 & 0.114 \\
\hline Primary & 23 & 15.54 & 23 & 13.69 & 46 & 0.073 \\
\hline Secondary & 17 & 11.48 & 29 & 17.26 & 46 & 0.054 \\
\hline Diploma/TVET & 14 & 9.46 & 40 & 23.81 & 54 & 0.044 \\
\hline Degree $\&$ above & 14 & 9.46 & 59 & 35.12 & 73 & 0.044 \\
\hline Grand Total & 148 & 100 & 168 & 100 & 316 & 46.84 \\
\hline
\end{tabular}
lower than others and they have equal footings of $4.4 \%$.

Table-5. Poverty incidence by level of educational achievements

\subsubsection{Income and Poverty}

In this study the average incomes of households per month in birr was taken as a base to classify households' income as lower, middle and higher. Therefore, the monthly income of households was divided as follows: the lower income ranges from 0-4040 birr, the middle income ranges from 4041-8000 birr, and the higher income ranges from 8001-1600 birr. As can be presented in Table 6 in the study area about $87.16 \%$ of the poor households and $44.64 \%$ of the non-poor households were found in the low income level range of $0-4040$ birr, $12.16 \%$ of the poor and $45.24 \%$ of the non-poor were found in the middle income range of $4041-8000$ birr, and $0.67 \%$ of the poor and 
$10.12 \%$ of the non-poor were found in the higher income range of 8001-1600 birr. As apparent from the table, the highest incidence of poverty $(87.16 \%)$ was observed in those households who were in the lower range of $0-4040$ birr.

Table-6. Poverty incidence by level of household income.

\begin{tabular}{|c|c|c|c|c|c|c|}
\hline \multirow{3}{*}{ Income range } & \multicolumn{4}{|c|}{ Households Poverty Status } & \multirow{3}{*}{ Total } & \multirow{3}{*}{$\begin{array}{c}\text { Headcount } \\
P_{0}\end{array}$} \\
\hline & \multicolumn{2}{|c|}{$\begin{array}{c}\text { Poor } \\
\text { households }(\mathrm{N}=148) \\
\end{array}$} & \multicolumn{2}{|c|}{$\begin{array}{c}\text { Non-poor } \\
\text { households }(N=168)\end{array}$} & & \\
\hline & Frequency & Percent & Frequency & Percent & & \\
\hline $0-4040$ & 129 & 87.16 & 75 & 44.64 & 204 & 0.408 \\
\hline $4041-8000$ & 18 & 12.16 & 76 & 45.24 & 94 & 0.057 \\
\hline $8001-16000$ & 1 & 0.675 & 17 & 10.12 & 18 & 0.003 \\
\hline Grand Total & 148 & 100 & 168 & 100 & 316 & 0.468 \\
\hline
\end{tabular}

Table-7. Monthly income-expenditure gaps.

\begin{tabular}{|c|c|c|c|c|c|c|}
\hline \multirow{3}{*}{$\begin{array}{c}\text { Does your monthly } \\
\text { income cover your } \\
\text { monthly expenditure? }\end{array}$} & \multicolumn{4}{|c|}{ Households poverty status } & \multirow{3}{*}{ Total } & \multirow{3}{*}{$\begin{array}{c}\text { Headcount/ } \\
\mathbf{P}_{0}\end{array}$} \\
\hline & \multicolumn{2}{|c|}{$\begin{array}{c}\text { Poor } \\
\text { households }(\mathrm{N}=148)\end{array}$} & \multicolumn{2}{|c|}{$\begin{array}{c}\text { Non- poor } \\
\text { households }(N=168)\end{array}$} & & \\
\hline & Frequency & percent & frequency & percent & & \\
\hline Yes & 56 & 37.84 & 110 & 65.47 & 166 & 0.177 \\
\hline No & 92 & 62.16 & 58 & 34.53 & 150 & 0.291 \\
\hline Grand Total & 148 & 100 & 168 & 100 & 316 & 0.468 \\
\hline
\end{tabular}

The households' monthly income-expenditure gaps in the study area showed that from the poor category, $56(17.72 \%)$ of the households can able to cover their monthly consumption expenditure and 92(29.11) of the households were unable to cover their monthly consumption expenditure whereas in the non-poor category, majority of the households $110(34.81 \%)$ of the households can able to cover their monthly consumption expenditure and the remaining $58(18.35 \%)$ of the households were unable to cover their monthly consumption expenditure see Table 7 .

Table-8. Way of filling income - expenditure gaps/coping strategy of the poor.

\begin{tabular}{|c|c|c|c|c|c|}
\hline \multirow{3}{*}{$\begin{array}{l}\text { Ways of filling income-expenditure } \\
\text { gaps/coping strategy of the poor }\end{array}$} & \multicolumn{4}{|c|}{ Household Poverty Status } & \multirow{3}{*}{ Total } \\
\hline & \multicolumn{2}{|c|}{$\begin{array}{c}\text { Poor } \\
\text { households }(\mathrm{N}=148)\end{array}$} & \multicolumn{2}{|c|}{$\begin{array}{c}\text { Non-poor } \\
\text { households }(N=168)\end{array}$} & \\
\hline & frequency & percent & frequency & percent & \\
\hline By reducing amount of household consumption & 51 & 55.43 & 28 & 49.12 & 79 \\
\hline By selling valuable assets & 5 & 5.43 & 3 & 5.26 & 8 \\
\hline By purchasing low price \&low quality items & 36 & 39.13 & 26 & 45.61 & 62 \\
\hline Grand Total & 92 & 100 & 57 & 100 & 149 \\
\hline
\end{tabular}

The Table 8 provides, the majority of the households 51(55.43\%) said that they fill the income-expenditure gaps by reducing the amount of households monthly consumption, 36(39.13\%) fill the gap by purchasing and consuming low price and low quality items, and the remaining $5(5.43 \%)$ fill the gap by selling their valuable assets whereas in the non-poor category, $28(49.12 \%)$ of the households fill the gaps by reducing the amount of households monthly consumption, $26(45.61 \%$ ) fill the gap by purchasing and consuming low price and low quality items, and the remaining $3(5.26 \%)$ fill the gaps by selling their valuable assets. Thus, the outcome of the survey shows that $94.56 \%$ of the poor households fill their income-expenditure gaps by reducing the amount of consumption and by purchasing low price and low quantity items as a coping strategy for survival otherwise leading a meager life.

\subsubsection{Unemployment and Poverty}

From the total poor households, 58(39.19\%) have zero unemployed family members, 66(44.59\%) of the households have one unemployed family member in their house indicating that majority of the households have zero or one unemployed family member, and 24(16.22 \%) of the households have 2 unemployed family members. Similarly, from the total non-poor households, $131(77.97 \%)$ have zero unemployed family member, $30(17.86 \%)$ have one unemployed family members, and the remaining $7(4.17 \%)$ have 2 unemployed family member. As apparent from Table 9, the incidence of poverty was highest for those households having 1 unemployed family member with poverty incidence of $20.8 \%$, followed by households with zero unemployed family members and 2 unemployed family members with incidence of $18.4 \%$ and $7.6 \%$ respectively. Even if majority of the households have zero or one unemployed family members 124.(83.78\%) of the households couldn't escape from poverty and they were in the poor category see Table 9.

Table-9. Poverty incidence by number of unemployed household members.

\begin{tabular}{c|c|c|c|c|c|c}
\hline \multirow{2}{*}{$\begin{array}{c}\text { Unemployed } \\
\text { family members }\end{array}$} & \multicolumn{3}{|c|}{ Household Poverty Status } & \multirow{2}{*}{$\begin{array}{c}\text { Total } \\
\text { Non-poor } \\
\text { households(N=168) }\end{array}$} & $\begin{array}{c}\text { Headcount/ } \\
\mathbf{P}_{\mathbf{o}}\end{array}$ \\
\cline { 2 - 6 } & Frequency & percent & Frequency & percent & & \\
\hline 0 & 58 & 39.19 & 131 & 77.97 & 189 & 0.184 \\
\hline 1 & 66 & 44.59 & 30 & 17.86 & 96 & 0.208 \\
\hline Grand Total & 24 & 16.22 & 7 & 4.17 & 31 & 0.076 \\
\hline
\end{tabular}




\subsubsection{Home Ownership and Poverty}

As Table 10 reveals, 94(29.75\%) of the sampled households were lived in their own house, $215(68.04 \%)$ of the households do not have their own house and lived in private/rental houses, and the remaining7 (2.22\%) of the households were lived in their relative's houses. Majority of the sampled households were lived in private/rental houses and the incidence of poverty was also highest for these households with poverty incidence level of $35.4 \%$. Though, there was no equal proportion in the distribution of households, the lowest incidence level was observed for those households who were lived in their relative's houses and those households who were lived in their own house with incidence of $1.9 \%$ and $9.5 \%$ respectively.

Table-10. Poverty incidence by households homeownership.

\begin{tabular}{|c|c|c|c|c|c|c|}
\hline \multirow{3}{*}{ Household Homeownership } & \multicolumn{6}{|c|}{ Household poverty status } \\
\hline & \multicolumn{2}{|c|}{$\begin{array}{c}\text { Poor } \\
\text { households }(\mathrm{N}=148)\end{array}$} & \multicolumn{2}{|c|}{$\begin{array}{c}\text { Non-poor } \\
\text { households }(\mathrm{N}=168)\end{array}$} & \multirow[b]{2}{*}{ Total } & \multirow[t]{2}{*}{$\begin{array}{c}\text { Headcount } \\
P_{0}\end{array}$} \\
\hline & frequency & percent & frequency & percent & & \\
\hline Own house & 30 & 20.27 & 64 & 38.09 & 74 & 0.095 \\
\hline Private/Rental & 112 & 75.67 & 103 & 61.31 & 215 & 0.354 \\
\hline Relative's house & 6 & 4.05 & 1 & 0.59 & 7 & 0.019 \\
\hline Grand total & 148 & 100 & 168 & 100 & 316 & 0.468 \\
\hline
\end{tabular}

\subsubsection{Health and Poverty}

Household health status is one of the determinants for the aggravation or improvement of poverty as many literatures proved from theoretical underpinnings. In this study households were asked to say Yes or No whether any of their household member frequently suffered from disease or not. As apparent from Table 11 from the poor households $107(33.86 \%)$ said Yes and the remaining $41(12.97 \%)$ said No, implying that there was no any household member who frequently suffered from disease. Whereas in the non- poor category, 92(29.11\%) of the households said Yes and the remaining 76(24.05\%) of the households said No, indicating that there was no any household member who suffered from disease. The incidence of poverty was also highest for those households whose family member frequently suffered from disease with incidence level of $33.8 \%$ and the lowest level of incidence was observed for those households that any of their family member were not frequently suffered from disease with incidence level of $12.9 \%$ indicating that households' health status/disease is the major determinant for the aggravation or improvement of the level of poverty in the study area. Moreover, the finding of the study revealed that household health/disease has significant impact on the incidence of poverty.

Table-11. Poverty incidence by household health status.

\begin{tabular}{|c|c|c|c|c|c|c|}
\hline \multirow{3}{*}{$\begin{array}{l}\text { Household members frequently } \\
\text { suffered from disease? }\end{array}$} & \multicolumn{4}{|c|}{ Household poverty status } & \multirow[b]{3}{*}{ Total } & \multirow{3}{*}{$\begin{array}{l}\text { Headcoun } \\
\mathbf{P}_{0}\end{array}$} \\
\hline & \multicolumn{2}{|c|}{$\begin{array}{c}\text { Poor } \\
\text { households }(\mathrm{N}=148)\end{array}$} & \multicolumn{2}{|c|}{$\begin{array}{c}\text { Non - poor } \\
\text { households }(\mathrm{N}=168) \\
\end{array}$} & & \\
\hline & frequency & Percent & frequency & percent & & \\
\hline Yes & 107 & 72.3 & 92 & 54.76 & 199 & 0.338 \\
\hline No & 41 & 27.7 & 76 & 45.24 & 117 & 0.129 \\
\hline Grand Total & 148 & 100 & 168 & 100 & 316 & 0.468 \\
\hline
\end{tabular}

As regarding the extent of city medical services provision status, the sampled households were asked about their evaluations about the quality and reliability of the medical services in the city. As apparent from Table 12 $44(13.92 \%), 201(63.61 \%), 68(21.52 \%), 3(0.95 \%)$ of the respondents said that the medical service provision in the study area was poor, good, very good, and excellent respectively. As apparent from the table, majority of the households' evaluation in the case of extent of medical services provision disclosed that city medical services provision was in good condition.

Table-12. Status of Debre Markos city health centers service provision.

\begin{tabular}{|c|c|c|c|c|c|}
\hline \multirow[t]{2}{*}{ Household poverty status } & \multicolumn{4}{|c|}{ City health centers service provision } & \multirow[b]{2}{*}{ Total } \\
\hline & Poor & Good & V.good & Excellent & \\
\hline $\begin{array}{c}\text { Poor } \\
\text { households }(\mathrm{N}=148)\end{array}$ & $\begin{array}{c}22 \\
(14.86 \%) \\
\end{array}$ & $\begin{array}{c}88 \\
(59.46 \%) \\
\end{array}$ & $\begin{array}{c}37 \\
(25 \%) \\
\end{array}$ & $\begin{array}{c}1 \\
(0.67 \%)\end{array}$ & 148 \\
\hline Non -Poor households( $\mathrm{N}=168$ & $\begin{array}{c}22 \\
(13.09 \%) \\
\end{array}$ & $\begin{array}{c}113 \\
(67.26 \%) \\
\end{array}$ & $\begin{array}{c}31 \\
(18.45 \%) \\
\end{array}$ & $\begin{array}{c}2 \\
(1.19 \%) \\
\end{array}$ & 168 \\
\hline Grand Total & 44 & 201 & 117 & 3 & 316 \\
\hline
\end{tabular}

As Table 13 reveals, regarding the degree of city health service intervention to solve health related problems households were asked about their evaluations. Accordingly, 19(6.01\%), 97(30.69\%), 168(53.15\%), 32(10.12\%) of the households said no attention given, little attention, some attention, and a lot attention respectively.

Table-13. Health centers intervention/attention to solve health related problems.

\begin{tabular}{c|c|c|c|c|c}
\hline \multirow{2}{*}{ Household poverty status } & \multicolumn{2}{|c|}{ City health centers attention to solve problems } & Total \\
\cline { 2 - 6 } & No attention & $\begin{array}{c}\text { Little } \\
\text { attention }\end{array}$ & $\begin{array}{c}\text { Some } \\
\text { attention }\end{array}$ & $\begin{array}{c}\text { lot } \\
\text { attention }\end{array}$ & $8(5.41 \%)$ \\
\hline Poor households $(\mathrm{N}=148)$ & $9(6.08 \%)$ & $54(36.48 \%)$ & $77(52.03 \%)$ & 148 \\
\hline Non - poor households $(\mathrm{N}=168)$ & $10(5.95 \%)$ & $43(25.59 \%)$ & $91(54.17 \%)$ & $24(14.28 \%)$ & 168 \\
\hline Grand Total & 19 & 97 & 168 & 32 & 316 \\
\hline
\end{tabular}




\subsubsection{Electricity and Poverty}

In this study, to assess household's access to electricity a question was posed to the households to check whether they have their own metered electricity or not. As can present in Table 14 the majority $274(86.71 \%)$ of the households in the study area have their own metered electricity. Specifically, from the poor category $125(84.46 \%)$ said yes and the remaining $23(15.54 \%)$ of the poor households said that they have no their own metered electricity. Whereas, from the non-poor category, $149(488.69 \%)$ of the households responded that they have their own metered electricity and the remaining $19(11.31 \%)$ said that they have no their own metered electricity. The incidence of poverty was also highest for those households who have their own metered electricity with incidence level of $39.5 \%$ while for those households who have no their own metered electricity they have a $7.2 \%$ of poverty incidence implying that access to electricity has no any meaningful impact to escape from poverty in the study area.

Table-14. Poverty incidence by access to electricity

\begin{tabular}{|c|c|c|c|c|c|c|}
\hline \multirow{3}{*}{$\begin{array}{c}\text { Household have } \\
\text { metered electricity? }\end{array}$} & \multicolumn{4}{|c|}{ Household poverty status } & \multirow[b]{3}{*}{ Total } & \multirow{3}{*}{$\begin{array}{c}\text { Headcount } \\
\mathbf{P}_{0}\end{array}$} \\
\hline & \multicolumn{2}{|c|}{ Poor households $(\mathrm{N}=148)$} & \multicolumn{2}{|c|}{ Non - poor households $(\mathrm{N}=168)$} & & \\
\hline & frequency & percent & frequency & percent & & \\
\hline Yes & 125 & 84.46 & 149 & 88.69 & 274 & 0.395 \\
\hline No & 23 & 15.54 & 19 & 11.31 & 42 & 0.072 \\
\hline Grand Total & 148 & 100 & 168 & 100 & 316 & 0.468 \\
\hline
\end{tabular}

\subsubsection{Water Supply and Poverty}

From theoretical underpinnings and as many literatures proved, water and sanitation contributes to poverty alleviation and to improvements in the standard of living in several ways. In this study to assess household's access to water and their main sources a question was posed to households to check whether they have access or not. As Table 15 reveals, majority of the households have their own pipeline in their compounds. From the total survey $209(66.14 \%)$ of the households have their own pipeline, $48(15.19 \%)$ of the households used public pipelines as their main source of water, $50(15.82 \%)$ of the households used private pipelines and the remaining $9(2.85 \%)$ used their own dug-well as a main source of water for the household. Specifically, $81(25.63 \%)$ and $128(40.51 \%)$ of the poor and non- poor households have their own pipelines in their compounds as a main source of water, $29(9.17 \%)$ and $19(6.01 \%)$ of the poor and non-poor households used public pipelines as their main source of water, 35(11.07\%) and $15(4.75 \%)$ of the poor and non-poor households used private water sources, and the remaining $3(0.95 \%)$ and $6(1.89 \%)$ of the poor and non-poor households used their own dug-well as a main source of water. As apparent from the table, the highest incidence of poverty $25.6 \%$ was observed in those households who have their own pipelines followed by households who used private water sources and public water as their main sources of water with incidence level of $11 \%$ and $9 \%$ respectively.

Table-15. Households main source of water supply.

\begin{tabular}{|c|c|c|c|c|c|c|}
\hline \multirow{3}{*}{$\begin{array}{l}\text { Household main source of water } \\
\text { supply }\end{array}$} & \multicolumn{4}{|c|}{ Household poverty status } & \multirow[b]{3}{*}{ Total } & \multirow{3}{*}{$\begin{array}{l}\text { Headcount } \\
P_{0}\end{array}$} \\
\hline & \multicolumn{2}{|c|}{$\begin{array}{c}\text { Poor } \\
\text { households }(\mathrm{N}=148)\end{array}$} & \multicolumn{2}{|c|}{$\begin{array}{c}\text { Non-poor } \\
\text { households }(N=168)\end{array}$} & & \\
\hline & Frequency & percent & frequency & percent & & \\
\hline Own pipeline & 81 & 54.73 & 128 & 76.19 & 209 & 0.256 \\
\hline Public pipe line & 29 & 19.59 & 19 & 11.31 & 48 & 0.0917 \\
\hline Private pipeline & 35 & 23.65 & 15 & 8.93 & 50 & 0.111 \\
\hline Own dug-well & 3 & 2.03 & 6 & 3.57 & 9 & 0.009 \\
\hline Grand Total & 148 & 100 & 168 & 100 & 316 & 0.468 \\
\hline
\end{tabular}

Regarding water service provision, to assess the status of city water service provisions in terms of quality and reliability households were asked about their evaluations. As can be presented in Table 16 majority of the surveyed households $170(53.79 \%)$ responded that the provision was in poor condition indicating that water service provision in the city was not in line with demand of the society. 108(34.17\%) said satisfactory, 36(11.39\%) said good and the remaining $2(0.63 \%)$ of the households said that city water service provision was in a very good position.

Table-16. City water service provision status in terms of quality and reliability.

\begin{tabular}{|c|c|c|c|c|c|}
\hline \multirow[t]{2}{*}{ Household poverty status } & \multicolumn{4}{|c|}{ City water service provision quality and reliability } & \multirow[b]{2}{*}{ Total } \\
\hline & V. good & Good & Satisfactory & Poor & \\
\hline Poor households $(\mathrm{N}=148)$ & $\mathrm{O}$ & $\begin{array}{c}17 \\
(11.48 \%) \\
\end{array}$ & $\begin{array}{c}50 \\
(33.78 \%) \\
\end{array}$ & $\begin{array}{c}89 \\
(60.14 \%) \\
\end{array}$ & 148 \\
\hline Non - poor households $(\mathrm{N}=168)$ & $\begin{array}{c}2 \\
(1.19 \%) \\
\end{array}$ & $\begin{array}{c}19 \\
(11.31 \%) \\
\end{array}$ & $\begin{array}{c}58 \\
(34.52 \%) \\
\end{array}$ & $\begin{array}{c}81 \\
(42.21 \%)\end{array}$ & 168 \\
\hline Grand Total & 2 & 36 & 108 & 170 & 316 \\
\hline
\end{tabular}

In this study to assess the extent of water supply service problem in Debre Markos city households were asked about their evaluations.

As apparent from Table 17 almost half of the surveyed households 151(47.78\%) said that there was a serious shortage of water in the city and the supply of water was not equipped with the demand of the society. While $106(33.54 \%)$ said less serious, 58(18.35\%) said too serious, and the remaining $1(0.31 \%)$ said that there was no problem regarding water supply. 
Table-17. Extent of Debre Markos city water service provision problem

\begin{tabular}{c|c|c|c|c|c}
\hline \multirow{2}{*}{ Household poverty status } & \multicolumn{2}{|c|}{ Extent of city water service provision problem } & \multirow{2}{*}{ Total } \\
\cline { 2 - 5 } & Too serious & Serious & Less serious & No problem & \\
\hline Poor households $(\mathrm{N}=148)$ & $27(18.24 \%)$ & $66(44.59 \%)$ & $54(36.48 \%)$ & $1(0.67 \%)$ & 148 \\
\hline Non - poor households( N=168) & $31(18.45 \%)$ & $85(5.59 \%)$ & $52(30.95 \%)$ & 0 & 168 \\
\hline Grand Total & 58 & 151 & 106 & 1 & 316 \\
\hline
\end{tabular}

4.3 Econometric Analysis and Model Evaluation Results

Heteroscedasticity test: A situation in which the variance of the dependent variable varies across the data. Many methods in regression analysis are based on the assumption of homoscedasticity or equal (homo) spread (scedasticity), that is, equal variance (Gujarati, 2004). In logit analysis there is no equal variance or homogeneity of variance assumptions and the variance of the error terms is not constant. In this analysis, Cook Weisberg test for heteroscedasticity (hettest) using fitted values of poverty is carried out in stata software. The result showed that the value of Chi-square $\mathrm{x} 2(1)=1.55$, and Prob $>$ value $=0.21$. Thus, the dependent variable varies across the data.

Table-18. Logistic regression result.

\begin{tabular}{c|c|c|c|c|c}
\hline Variable & Coefficient & Odd ratio & $\mathbf{Z}$ & Std. Err & dy/dx \\
\hline Age & -0.359 & 0.97 & -0.92 & 0.28 & -0.0065 \\
\hline Sex & -0.887 & 0.9236 & -0.14 & 0.49 & -0.0184 \\
\hline Ms & -0.39 & 0.8112 & -0.85 & 0.19 & -0.0511 \\
\hline Educ** & -0.01 & 0.7023 & -2.41 & 0.10 & -0.0863 \\
\hline Occup & -0.31 & 0.9263 & -1.01 & 0.07 & -0.0187 \\
\hline Fs*** & 0.00 & 5.37 & 5.13 & 1.75 & 0.4109 \\
\hline Income*** & -0.00 & 0.9989 & -5.60 & 0.0001 & -0.0002 \\
\hline Depen & -0.53 & 0.8196 & -0.62 & 0.262 & -0.0486 \\
\hline Unemploym* & 0.08 & 1.947 & 1.74 & 0.746 & 0.1629 \\
\hline Homown* & 0.09 & 2.243 & 1.69 & 1.07 & 0.1974 \\
\hline NWK & -0.40 & 0.9156 & -0.83 & 0.097 & -0.0215 \\
\hline Season & 0.75 & 1.183 & 0.31 & 0.64 & 0.0410 \\
\hline Credit & 0.17 & 1.771 & 1.35 & 0.75 & 0.1397 \\
\hline HHHS*** & -0.00 & 0.2092 & -3.47 & 0.094 & -0.3822 \\
\hline Water & 0.17 & 1.420 & 1.36 & 0.36 & 0.0858 \\
\hline Elt & 0.25 & 1.989 & 1.13 & 1.20 & 0.168 \\
\hline Tel & -0.57 & 0.5214 & -0.56 & 0.610 & -0.1591 \\
\hline Cons & -0.75 & 0.4326 & -0.32 & 1.14 & \\
\hline Source: Own survey data, $2017^{* * *} * * * *$ \\
\hline
\end{tabular}

The variable that are negatively correlated with the probability of being poor are age, sex, marital status, education, occupation, income, dependency, number of working hours, household health status. Positively correlated with the probability of being poor were family size, house ownership, unemployment, seasonality of work, access to credit, water source, and electricity. In the Table 18 of 17 independent variables, six of the variables family size, education, income, unemployment, house ownership and household health status have a significance level at $1 \%, 5 \%$, and $10 \%$. The negative values of explanatory variables indicates that when the unit change in independent variable lead to decrease in probability of being poor.

The better educational achievements diminish the probability of a household being poor and it is found statistically significant at 5\% significance level. The coefficient of education in the regression results showed that a level increase in education (a one year increase on the number of years of schooling) will result in $8.6 \%$ decreases in the probability of a household becoming poor.

Family size was found statistically significant at $1 \%$ significance level and have positive impact on the probability of a household becoming poor. As can be seen from table 33, an addition of one extra member to the household will result a $41 \%$ probability of a household becoming poor. This is not peculiar only in Debre Markos but most developing countries. Babatunde et al. (2008); Apata et al. (2010) they argued that, poverty increases with increasing in family or household size because large family size tends to reduce the per capita income available to the household.

The income of household has statistically significant at $1 \%$ significance level and negative impact on the probability of a household being poor in the study area. As a one birr increase in per adult equivalent income of the household decreases the probability of a household falling in to poverty by $0.025 \%$. However, its effect was not as big as expected since urban poverty is mostly determined by income earning capacity especially cash money.

As expected, unemployment (having larger unemployed family members) in a household was found statistically significant at 10\% significance level and has positive impact on the probability of being poor. That means, a household having one extra unemployed family member result in $16.3 \%$ increase in the probability of becoming poor in the study area.

The regression result showed that home ownership (households who had no a residential house) was found statistically significant at $10 \%$ significance level and it is a positive correlate to poverty. That means, as a household had no his/her own house, the probability of a household becoming poor increases by $19.7 \%$. This is in line with the view that, as a household own a house the cost that were to be paid as a rent will be saved and the house itself can be used as a productive asset.

The household health status has found statistically significant at $1 \%$ significance level and negative impact on the probability of being poor. As apparent from Table 18 households with better health status or those households whose family member is not frequently suffered from disease decreases the probability of a household becoming poor by $38.2 \%$. 


\section{Conclusions and Policy Implications}

- To reduce urban poverty and to promote urban livelihood, a useful place to start is with poverty reduction arrangements based on poverty analysis aimed at identifying the contributing factors of urban poverty. Based on the empirical findings of the study, the researcher portrays the following policy implications to mitigate poverty at a household level.

- The findings of the study showed that, in the study area the proportion of the poor people is estimated to be $46.8 \%$ indicating that almost half of the people were unable to meet the monthly per adult consumption expenditure of 315 ETB. Moreover, the national HICES survey result shows that the poor urban households require only $7.3 \%$ at national level and $8 \%$ in the region. However, in the study area it was found that there is a requirement of $34.4 \%$ to escape from the poverty group. The poverty severity index was $37.4 \%$ in the study area while, it was $2.9 \%$ at national level and $3.2 \%$ in the region. Therefore, one of the policy implications of the present study is that the ongoing national and regional governments' policy intervention should target $37.4 \%$ of the poorest of the poor that needs an immediate and a joint policy intervention by the government and other stakeholders.

- Urban poverty alleviation is impossible unless the existing economy should generate opportunities for investment thereby job creation and sustainable livelihoods. In the study area households' evaluation of the level of investment and its job creation is almost negative indicating that investment has no significant impact on poverty reduction efforts and in the process of improving residents' life standard. Therefore, there is a need for policies and strategies that create an enabling environment to attract new investments and promoting the existing ones.

- Though the cost of housing/rent is one of the main contributing factors to urban poverty, the study showed that in the study area majority of the residents, about $68 \%$ have no their own house rather they were lived in private/rental houses. Therefore, the prices that were paid as a rent just increases the residents cost of living. The policy implication of this study is that, there is a need that governments of developing countries like Ethiopia should expand their housing program to support 'non-conventional' incremental social housing, that is, the production of good quality public housing that includes socially controlled rental accommodation that is affordable to those households in the lowest income groups. Given that most of the management and administration of urban housing in most developing countries are handled by the central governments, there should be devolution of authority in the housing sector to the regional and local levels so that the increasing needs of the public can be met in short waiting time. As a general remark, public authorities or concerned bodies need to establish policies and strategies that address the problem of housing especially mechanisms(which are accessible by the poor) to address the poor through the provision of land for construction purpose, construction of condominium houses at affordable prices and other options.

- Urban poverty reduction efforts should be made at the grass root level through the provision of basic social services. Inability to afford essential public services of adequate quality and quantity like water can cause unhygienic living conditions and ill health. In the present study the analysis showed that, there is a serious shortage of water and the service provision was in poor conditions. Households' evaluations of educational provision in terms of quality and quantity were also negative and the provision is not equipped with the needs of the society. Therefore, public authorities, city water service, and other stakeholders should try to address these social service problems and devise mechanisms to provide adequate and quality water and educational services to the society.

- The findings of the study showed that, poverty and family size were found significant positive correlates in the study area. Therefore, the policy implication of this study on such an issue is that so as to reduce the impact of larger family size on poverty, city health service and other stake holders should take a remedial action through extension services awareness creation about the impact of larger family size on poverty and family planning especially targeting on the poor.

- Generally, efforts should be made to raise the real income of households through well-paying and steady job creation by the setup of micro and small scale enterprises, with the increased provision of economic and social infrastructure of houses, education, and better water sanitation services for poverty reduction.

\section{References}

Apata, T.G., O.M. Apata, O.A. Igbalajobi and S.M.O. Awoniyi, 2010. Determinants of rural poverty in Nigeria: Evidence from small holder farmers in South-Western, Nigeria. Journal of Science and Technology Education Research, 1(4): $85-91$.

Aredo, D., 2005. Migrant remittances, shocks and poverty in urban Ethiopia: An analysis of micro-level panel data. Addis Ababa University, Addis Ababa, Ethiopia.

Babatunde, R., E. Olorunsanya and A. Adejola, 2008. Assessment of rural household poverty: Evidence from South-Western Nigeria. American-Eurasian Journal Agriculture and Environmental. Science, 3(6): 900-905.

Bigsten, A., B. Kebede, A. Shimeles and M. Taddesse, 2003. Growth and poverty reduction in Ethiopia: Evidence from household panel surveys. World Development, 31(1): 87-106.Available at: https://doi.org/10.1016/s0305-750x(02)00175-4.

CSA, 2010. FDRE General Country Data.

CSA, 2013. Population Projection of Ethiopia for All Regions at Wereda

CSA (Central Statistical Agency), 2007. Population and housing census 2007. Addis Ababa: Federal Democratic Republic of Ethiopia.

Debre, M., 2016. Debre Markos Municipality Annual Report (Amharic Version).

Dercon, S. and K. Pramila, 2003. Poverty in rural Ethiopia 1989-95: Evidence from household panel data in selected villages. In The New Poverty Strategies. London: Palgrave Macmillan. pp: 179-202.

Dercon, S. and M. Taddesse, 1997. A comparison of poverty in rural and urban ethiopia. Mimeo, centre for the study of african economies and department and addis ababa university.

Disney, R., A. Kedir and A. McKay, 2003. Price deflators and food poverty in urban Ethiopia. Mimeo, University of Nottingham.

Esubalew, 2006. Determinants of urban poverty: The case of debre Marekos. Ethiopian Economics Association Proceeding of the Fifth International Conference on the Ethiopian Economy, Addis Ababa, Ethiopia, 2: 37 -60.

Gujarati, 2004. Basic econometrics. 4th Edn., New York: Mc Graw-Hill, Inc.

Kedir, A.M. and A. McKay, 2003. Chronic poverty in urban Ethiopia: Panel data evidence. International Planning Studies, 10(1).Available at: https://doi.org/10.1080/13563470500159246. 
Lanjouw, P. and R. Martin, 1995. Poverty and household size. The Economic Journal, 105(433): 1415-1434.

Ministry of Finance and Economic Development (MoFED), 2013. Development and poverty in Ethiopia 1995/96-2010/11.Ministry of Finance and Economic Development, Addis Ababa, Ethiopia.

OPHDI, O.P.A.H.D.I., 2013. Ethiopia country briefing. Multidimensional poverty index data bank. Ophi, University of Oxford. Available from www.ophi.org.uk/multidimensional-poverty-index/mpi-country-briefings/.

Sharma, P., S. Dwivedi and D. Singh, 2016. Global poverty, hunger, and malnutrition: A situational analysis. In Biofortification of food crops. New Delhi: Springer. pp: 19-30.

Sumner, A. and T. Meera, 2015. Global poverty reduction to 2015 and beyond: What has been the impact of the MDGs and what are the options for a post-2015 global framework?. IDS Working Papers 2010.348 (2010): 01-31.

United Nations Development Programme, 2014. Human development report 2014. New York: Sustaining Human Progress: Reducing Vulnerability and Building Resilience. 